\title{
Prevalência e Sorotipagem de Salmonella em Linfonodos e Fezes de Suínos
}

João Bosco Pereira Guerra Filho (I), Silvia Janine Veiga (I), Fábio Sossai Possebon (I), Mateus José Sudano (II), Júlia Arantes Galvão (I), Ricardo Seiti Yamatogi (I), José Paes de Almeida Nogueira Pinto

(I) FMVZ/UNESP Botucatu - Universidade Estadual Paulista "Júlio de Mesquita Filho" (Distrito de Rubião Junior s $/ \mathrm{n}^{\circ}$, 18.618-970 Botucatu, São Paulo, Brasil), (II) UNIPAMPA Uruguaiana Universidade Federal dos Pampas (BR 472 Km 592 - Caixa Postal 118 Uruguaiana, RS CEP 97500-970)

\section{Resumo}

A carne suína é uma importante fonte de nutrientes, sendo a mais consumida no mundo. Todavia, relatos de veiculação de micro-organismos nocivos para a saúde através do produto são frequentes. Dentre tais, podese destacar Salmonella. Etapas da produção e transporte dos animais podem propiciar condições para a proliferação desta bactéria no trato gastrintestinal dos suínos, que associadas a falhas no processamento industrial podem levar a contaminação do alimento. Sabendo que a infecção dos animais se dá predominantemente por via oral, os linfonodos atuam como barreira primária ao patógeno; porém, posteriormente, tais animais podem acabar se tornando reservatórios do mesmo, liberando-o ao ambiente. Assim é adotado o isolamento de Salmonella a partir de linfonodos para indicar o status de portador, visto que a análise do conteúdo intestinal revelar o caráter excretor do animal. Deste modo, foi pesquisada a presença de Salmonella em fezes e em linfonodos mesentéricos, mediastínicos e submandibulares de 50 suínos abatidos sob Inspeção Federal no interior de SP e caracterizados seus sorovares. As amostras foram encaminhadas ao Laboratório da Disciplina de Inspeção de Produtos de Origem Animal, da Faculdade de Medicina Veterinária e 
Zootecnia - UNESP Campus Botucatu. A metodologia para isolamento de Salmonella spp. foi realizada como preconizada pelo Bacteriological Analytical Manual - BAM. A prevalência do patógeno foi de $10 \%$ no total das amostras, sendo os maiores índices encontrados nos linfonodos submandibulares com $20 \%$ positivos, seguido dos mesentéricos (18\%) e fezes com $2 \%$. Não houve resultados positivos nos mediastínicos. Linfonodos com as maiores prevalências encontram-se em regiões anatômicas intimamente relacionadas com o trato gastrintestinal. Dentre os sorovares identificados, o de maior prevalência foi $\mathrm{S}$. Typhimurium em 55\% das amostras. Diversos trabalhos reportam este sorovar como um dos principais associados à cadeia produtiva suína. O segundo sorovar mais prevalente foi S. entericasubspécieenterica 4,5,12:i:- que vem sendo reportado como uma importante variante emergente do patógeno. Foram ainda isolados os sorovares S. Brandenburg e S. Derby em uma amostra cada. Tais dados ratificam a importância da pesquisa de Salmonella em linfonodos suínos, bem como a necessidade de vigilância constante e identificação dos sorovares envolvidos.

Palavras-Chave: Salmonella, Suínos, Linfonodos, Fezes Agência de Fomento: 